\title{
実大鉄骨柱の高温座屈耐力に関する実験的研究 EXPERIMENTAL STUDY ON BUCKLING LOADS OF STEEL COLUMNS UNDER ELEVATED TEMPERATURES IN LARGE SCALE
}

\author{
茂木 武*, 遊佐 秀逸**, 西田一郎***, 岡 村 義 徳****, 仲谷一 郎***** \\ Takeshi MOTEGI, Syuitu YUSA, Ichirou NISHIDA, \\ Yoshinori OKAMURA and Ichirou NAKAYA
}

\begin{abstract}
The buckling loads of steel columns in large scale under elevated temperatures that are achieved by fire tests are discussed in this paper. The ISO standard and the other heating tests with loading through rounded supports were done for 24 specimens covered with some kind of thermal insulation. H-shape steelworks of the steel grades of SN400B and SS400 which have several different section sizes specified in the JIS standard and the support lengths of specimens are 3.8, 3.5 or 3.0 meters. After the careful observation of tests results, authors concluded as followings: The collapse loads of the columns can be obtained from the test results of mean steel temperatures between $34^{\circ} \mathrm{C}$ and $739^{\circ} \mathrm{C}$. The contraction of the columns can be induced by load, steel temperature and some other parameters. Although the allowable temperature of a column with the maximum service load by the AIJ design method for the 2.4 tonf $/ \mathrm{cm}^{2}$ yield strength and the 2100 tonf $/ \mathrm{cm}^{2}$ Young's modulus, is revealed to be less than $513^{\circ} \mathrm{C}$ or so, the buckling loads decreased with the temperature increase from ambient to $739^{\circ} \mathrm{C}$.
\end{abstract}

Keywords: Buckling load, Fire-resistance, Large-scale fire test, High temperature strength, Steel column. 座屈耐力、耐火性能、実大耐火試験、高温強度、鉄骨柱

\section{1.はじめに}

建築には鋼材が多く利用されており、火災のような高温現象に直 接これらがさらされた場合には、鋼材の温度が相当程度上昇する。 この温度上昇により鋼材強度は部材に作用する荷重を支持すること ができない程に低下寸ることが知られている ${ }^{1)}$ 。

鋼部材の温度上昇を防ぐ方法の一つとして部材周囲に断熱材を取 り付け、火災時の鋼材温度を構造上安全とされる温度 $\left(350^{\circ} \mathrm{C}\right)$ 以下にするための処置（いわゆる耐火被覆）が鋼部材には施されて いる。この構造上安全な鋼材温度は、それまでに行われた一連の実 験的2）3）あるいは理論的4）5）研究を基に決定された值である。

一方、耐火性能を評価寸る方法としては耐火試験方法 ${ }^{6}$ ) 7) があ り、現在の運用は主に鋼材温度に注目寸る方法を採用しているため 耐火被覆材の断熱性能を評価するものとなっているが、I S O 等8) 9) の試験方法では部材に荷重を作用させた状態で加熱試験し、荷 重支持能力が失われる時点を評価の対象としている。この差が、例 えば安全とされる鋼材温度の差として評価規定に表れている10)。

また、国際貿易の観点からこのような差が、貿易障壁の一つであ るとの認識にもとづき、I S Oによる国際的な試験規格統一の動き がある。これに対応するため日本の耐火試験をI S O規格に適合さ せるための研究が進められており、その結果が文献 [ 111$]$ に報告
されている。

本研究は、その中 ${ }^{11)}$ の鉄骨柱の実験結果を座屈荷重と鋼材温度 の関保に注目してまとめたものである。まとめるにあたっては、数 值実験及び単純塑性理論に基づき架構の高温安全性を明らかにした 文献 $\left[\begin{array}{ll}1 & 2\end{array}\right]$ で定義される崩壊温度の概念を、載荷耐火試験で座屈 した鉄骨柱（両端ピン支持）の座屈時鎆材温度に対忘させた。

\section{2. 研究の概要}

常温での鉄骨柱の座屈耐力はオイラー及びジョンソンの座屈式 等により計算され、長期态力に対する許容圧縮応力はこれに安全率 を考慮して決定される ${ }^{13)}$ 。本研究では、これに基づく荷重を鉄骨 柱に加えた加熱実験等により室温から $739^{\circ} \mathrm{C}$ の範囲で、座屈耐力 (以下、高温座屈耐力と言う) とその時の平均鋼材温度（以下、崩 壊温度と言う）の関係を求めるとともに、現行の耐火試験評価基準 である許容平均鋼材温度 $350^{\circ} \mathrm{C}$ 安全性を載荷加熱実験により検 証したものである。加えて実験結果をモデル化し、統計的方法によ りモデル定数を決定することで、高温座屈耐力と載荷加熱時の柱軸 方向伸縮量を予測する実験式を提案している。

\section{1 研究の方法}

\footnotetext{
* 建築研究所第五研究部防火材料研究室 主任研究員

** 建築研究所第五研究部防火研究 調整官・博士 (工学)

*** 建材試験センタ一中央試験所試験管理課

**** 日本建築総合試験所耐火防火試験室 主查

***** 建築研究所第五研究部防火材料研究室 室長·博士(工学)

Chief Research Engineer, Fire Preventive Material Division, Building Research Institute

Assoc. Director for Fire Safety Division, Building Research Institute, Dr. Eng. Engineer, Japan Testing Center for Construction Materials Chief Engineer, General Building Research Corporation of Japan Head for Fire Preventive Material Division, Building Research Institute, Dr. Eng.
} 
研究は、はじめに現在実施されている許容平均鋼材温度 $350{ }^{\circ} \mathrm{C}$ の判定基準（この他に最高温度 $450^{\circ} \mathrm{C}$ 基準があるが、この值に ついては調整できないため対态しなかった）を規定の荷重を支持し た柱に適用し、鉄骨柱の安全性を確認する。その後、鉄骨柱の高温 座屈耐力を I S Oに規定される載荷加熱試験等により調べる。これ らの目的で以下の 3 種類の実験を行った。

(1)の実験は、鉄骨柱に長期応力に対する許容圧縮応力度 ${ }^{13)}$ を生ず る荷重（以下、長期許容圧縮荷重と言う）の1．2 倍を作用させ た状態 6) で加熱実験を行い、平均鋼材温度が告示、JISに規定 される許容値の $350^{\circ} \mathrm{C}$ に達した時点で加熱を停止し、柱が加熱 停止後の銅材温度上昇によっても荷重支持能力を失わないことを 確認するための実験である。

一般に、耐火被覆された鉄骨柱の鋼材温度は加熱停止後も上昇 し、ある時間経過後に最高温度に達寸る。その時の温度と時間は 耐火被覆の種類により異なるため、ここでは代表的耐火被覆材料 について加熱停止後の温度上昇によっても柱が荷重支持能力を失 わないことを確認する。

(2)の実験は、(1)の実験全てで武験体が荷重を健全に支持していたた め、実験後の試験体を再利用して行ったものである。実験は試験 体の荷重を一度下げた後（転倒防止のため完全には除荷できな い）、試験体を放置椧却したり、加熱するなどの方法により目標 鋼材温度に調整し（1 体については加熱せずに常温で実施，T C - 10 （2)）、その温度で荷重を増加させて柱を破填し耐力を調べ るものである。これは一般の構造実験で用いられる方法と同じで、 鋼材温度の高い点のみが異なる。

(3) の実験は、I S Oに規定される載荷加熱試験 ${ }^{8)}$ で、荷重を柱に 加えた状態で試験を行ない、柱軸方向伸縮量と伸縮速度により荷 重支持能力が失われた時点を判定するものである。

試験体に施した耐火被覆は、代表的な材料として吹付ロックウー ルとケイ酸カルシュウム板を、加熱停止後の温度上昇の大きい材料 としてプラスチック粒子を含有する軽量モルタルを選んだ。また、 参考のため耐火被覆していない柱（無被覆，TC-1 (3)）に対して 同様の載荷加熱試験を行った。

被覆材厚さは、既に耐火構造として指定されている值を参考に耐 火 2 時間に相当する被覆厚さを選んだ。ただし、2つの試験体につ いては、鉄骨内により大きな温度の不均一を生じさせる目的で両フ ランジの片側、あるいは一方のフランジ全部の被覆厚さを半分にし た（詳細は図-2に示寸）。また、細い柱 $(\mathrm{OC}-10 ， 11)$ で は被覆厚さ $25 \mathrm{~mm}$ とした。

被覆厚さを耐火 2 時間相当と比較的厚く選んだ理由は、加熱時間 を長くすることで加熱初期（約 30 分まで）の不安定な加熱の影響 を相対的に小さくしトータルな加熱外力を安定させるためと、被覆 が厚ければ鋼材温度の上梨に時間を要するため、鋼材断面内温度が より均一化され、断面内温度の不均一による実験結果への影響を小 さくできると考えたためである（部分的に被覆厚さを薄くした 2 体 は除く）。なお、被覆厚さは耐火 2 時間を目標にして選んだが、実 際の加熱時間は 2 時間とは異なる。それは目標の鋼材温度に達する まで、或いは荷重支持能力を失うまで加熱を行ったためである。

載荷は主に中心圧縮で行い、3 試験体については偏芯圧縮を実施 した。荷重は上下の球座を介して導入し加熱中一定に保持した。但
し、財団法人 日本建築総合試験所の長さ $3 \mathrm{~m}$ の試験体では、上球 座部を図ー1（a）に示す方法とした。上下球座により加力点は回 転自由の条件となることを期待している。加カシステムの概要を図 -1 に示才。

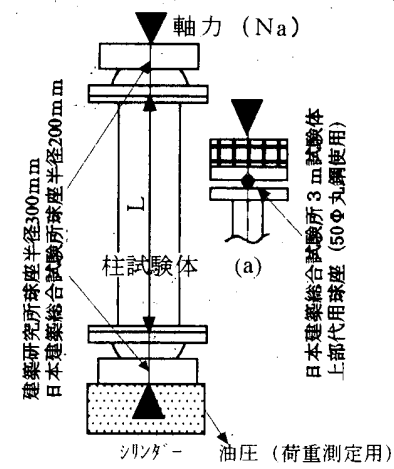

図一 1 加カシステム図

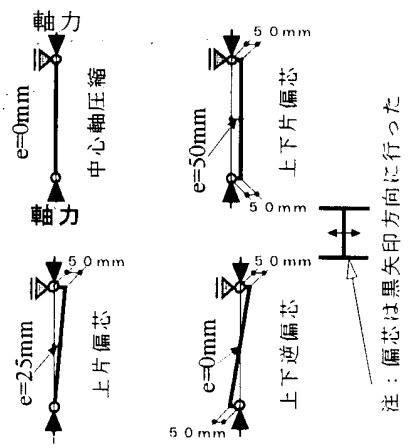

e: 柱高さ中央での偏芯量

\section{2 試匼体}

試験体の総数は 24 体で、 5 種類のH形鋼を用い、鋼種はS N 4 O O B S S 400 O 種である。試験体高さは建筑研究所では 3 . $8 \mathrm{~m}$ 、日本建築総合試験所では $3.5 \mathrm{~m}$ あるいは $3 \mathrm{~m}$ である。

試験体の上下端にはベースプレート（３２または３０t）．を溶接 し、ベースプレートの球座面は建築研究所ではプレーナー加エとし、 日本建築総合試験所では加工を施さなかった。試験体の概要と温度 測定点等を図一 2 に、試験体仕様（実験結果である崩填温度を含む） は表一 1 に示す。

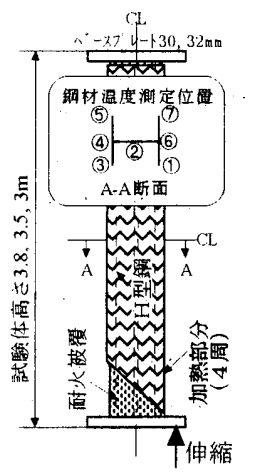
耐火被覆の形式
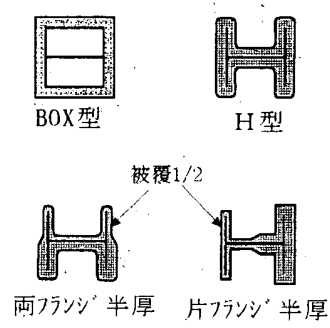

図 -2 伸縮 $\cdot$ 鋼材温度測定位置等

\section{3. 実験結果}

ここでは柱の高さ方向中央で測定した鋼材温度 7 点の算術平均 (以下、平均鋼材温度と言う) と試験体高さ方向の伸縮量測定結果 （以下、伸縮と言う）を用いて考察を行う。なぜなら、本研究が銅 材温度に対する柱の性能に注目して研究を進めているためである。 そして平均鋼材温度を代表温度に採用する理由は、柱試験体長さの 中央 $1 / 3$ では鋼材温度があまり違わないこと、およびこの部分の 温度が柱崩罣に大きく影響していると考えたためである。事実、実 験では柱の中央部付近が座屈してくくの字に曲がって壊れている し、既往の研究 ${ }^{14)}$.での扱いも同様なものである。

\section{1 平均鋼材温度 $350^{\circ} \mathrm{C}$ 安全性検証}

これは(1)の方法による実験である。したがって、平均銅材温度が 
表一1柱試験体の仕様等 (建築研究所十日本建築総合試䠼所, 但し、実験結果である崩壊温度を含む)

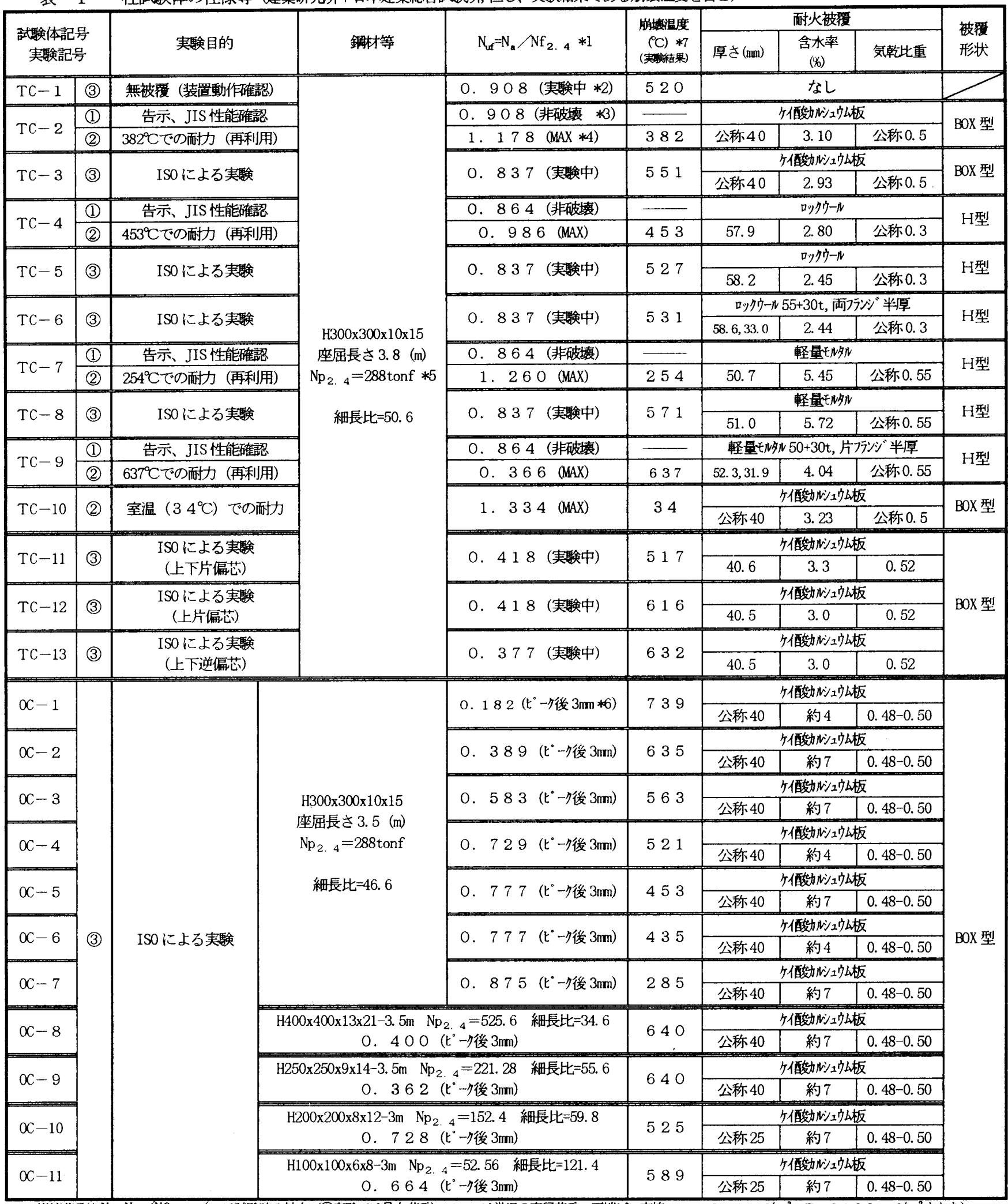

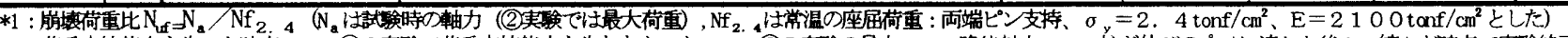

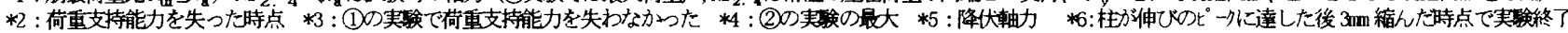

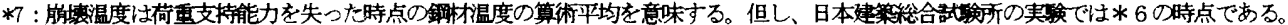

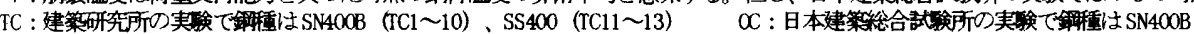

$350^{\circ} \mathrm{C}$ に達した時点で加熱を停止している。図ー 3 に 4 試験体の 平均銅材温度と伸縮の関係を示す。この図は加熱停止後に銅材温度 が後追い上昇し、その後の冷却により温度が下がる部分も含む結果 である。全ての実験で平均鋼材温度が低下に転じ、伸縮がある程度
戻った状態で荷重を支持していることを確認している。

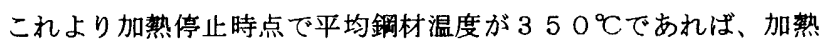
停止後の後追い温度上昇があっても、今回使用した耐火被覆を含む 試験体では荷重支持能力を失っていない。ちなみに、後追い温度上 


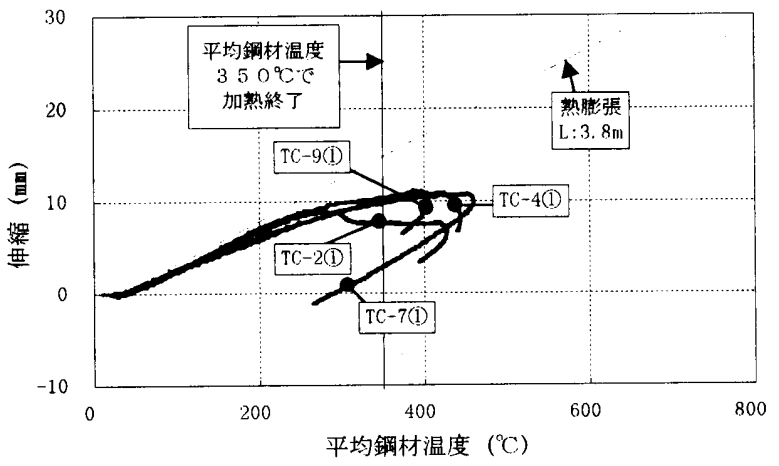

図- 3 平均鋼材温度と伸縮（告示、JIS）

犁を含む平均鋼材温度の最大值は $459^{\circ} \mathrm{C}$ で軽量モルタルの試験体

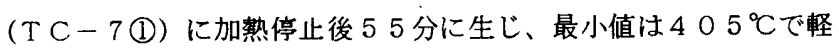
量モルタルの試験体（TC-9 1)で片側フランジの被覆厚さが半分 のもの) に加就停止後 29 分に生じている。

全体的傾向として、伸縮は平均鋼材温度の上昇とともに增加し、 上に凸の緩いカーブを描き最高温度より少し低い温度で减少し始め ている。但し、T C - 2 (1) (ケイ酸カルシュウム板) は約 $300{ }^{\circ} \mathrm{C}$ で伸縮が低下しているが原因は明らかでない。また、これら試験体 のフランジ間最大温度差はT C - 9 (1)で $327^{\circ}$ Cあった。従ってフ ランジ閒の温度差がこの程度であれば荷重支持能力は確保されると 言える。図一3には鋼の熱膨張による伸びの線を示寸が、測定され た伸縮は平均鋼材温度の低い範囲でこれに対応している。

\section{2 一定銅材温度での高温座屈耐力（荷重と伸綿）}

これは(2)の方法による実験である。即ち、試験体鋼材温度を目標 温度 (20、250、350、400、650 ${ }^{\circ}$ ) より少し高い温 度に調整し、その後の泠却により鋼材温度が目標值近くになってか ら（室温は除く）、荷重を順次増加させて柱を破壊した。この実験 では実験の手順上、荷重を増加させる間にも鋼材温度が低下するた め、目標温度と座屈時点の鋼材温度は異なり、荷重支持能力を失っ

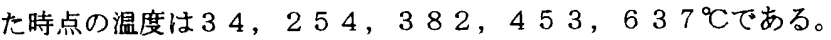
その際、鉄骨断面内の温度分布については、調整の方法もないこと から成り行きにまかせた。

図ー4に 5 試験体の荷重と伸縮の関倸をを示す。この図より座屈

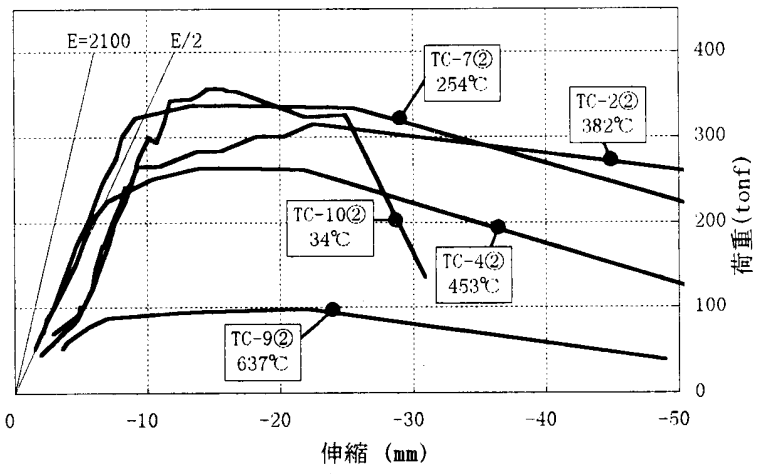

図-4 荷重と伸縮（定温破壊）

荷重は平均鋼材温度の上昇ととも低下し、座屈は伸縮量約 $-25 \mathrm{~m}$ m以内（縮み０．65\%）で生じていることがわかる。柱が座屈し た時の最大荷重を常温の座屈荷重（降伏強度を 2.4 tonf $/ \mathrm{cm}^{2}$ に、 ヤング率を2 100 tonf $/ \mathrm{cm}^{2}$ と仮定し、ジョンソン式とオイラー式
を降伏強度の0．6倍の位置で接続した座屈曲線による座屈荷重） との比（以下、崩壊荷重比と言う）で表わせば、平均鋼材温度 $34^{\circ} \mathrm{C}$ で1. $33 、 254{ }^{\circ} \mathrm{C}$ で1.26、38 $2^{\circ} \mathrm{C}$ で1. $17 、 453^{\circ} \mathrm{C}$ で0.98、637 9 Cで0.36である。

一方、鋼材温度の上昇に伴なうヤング率の低下傾向は各試験体の 荷重一伸縮曲線の初期勾配で特徴づけられるが、伸縮の小さい範囲 を除けば 34 〜 $533^{\circ} \mathrm{C}$ 籁囲ではあまり低下していない。なお、 図中のE、E／2の直線は荷重により伸縮のみが生じると仮定して 計算したヤング率 $2100 \mathrm{tonf} / \mathrm{cm}^{2}$ と、その半分の荷重一伸縮関係 を示している。測定された $34{ }^{\circ} \mathrm{C}$ 伸縮一荷重関係はEの線よりや や傾斜が少ないが、これは反力架棈の剛性が小さいためであると考 えられる。

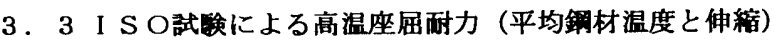

これは(3)の方法による載荷加熱試験である。試験は主に中心圧縮 で行い、偏芯圧縮（３体）も実施した。

中心圧縮試験の荷重は、ミルシート值あるいは別途実施した引張 り試酫の降伏強度による長期許容圧縮荷重の約 $1 / 5,1 / 2,3$ $/ 4 ， 1 ， 6 / 5$ を目標に選んだ。崩罣荷重比の計算には、(2)実験 の最大荷重の代わりに、試験中一定に保持した荷重を用いた。

偏芯圧縮実験は、偏芯圧縮による高温座屈耐力の変化を調べるこ とを目的としている。偏芯圧縮の試験体は 3 体（T C - 11 (3)〜 1 3 (3)）で、それぞれ偏芯状態を変えてある（詳細は図 1 参照）。偏 芯の方法としては、試験体上下ベースプレートの加力中心を $\mathrm{H}$ 形龬 の断面中心から強軸方向（ウエブ面外方向）に、上下端部に生じさ せるモーメントの方向に合わせて $50 \mathrm{~mm}$ 移動させた。荷重の大き さは、試験体の高さ方向の上中下断面（上、下はベースプレートか ら $205 \mathrm{~mm}$ 晟れた位置) に取り付けたストレイングージの圧縮側 歪み值（縁応力位置）の最大が 1.6 tonf $/ \mathrm{cm}^{2}$ の応力度に相当する 荷重を迸入した。一般に、端部に曲げと軸力を受ける柱（偏芯圧縮 と等価）の座屈耐力は軸力のみが作用寸る場合の耐力に比較して小 さくなることから理解できるように、偏芯柱に導入した荷重は、上 下ピン支持された柱の長期許容圧縮荷重より小さくなった。

試験体 $O C-10$ (3)とOC-1 1 (3) されている陚験体と同じ鋼材寸法、荷重による実験で、ここでの結 果と文献2)の結果を比較するために行った。

I SOの試験規格では、柱の荷重支持能力を失う時点の判定は伸 縮量と伸縮速度で行なわれ、それぞれの許容值は式（1）、（2） で計算される。規定では両方の值を超えた時点で荷重支持能力を失 ったと判定する。

$$
\begin{aligned}
\mathrm{C}_{\mathrm{a}} & =\frac{\mathrm{h}}{100} \\
\frac{\mathrm{dC} \mathrm{a}}{\mathrm{dt}} & =\frac{3 \times \mathrm{h}}{1000}
\end{aligned}
$$

ここに Ca: 許容軸方向伸縮 $(\mathrm{mm}) \mathrm{h}$ :試験体高さ $(\mathrm{mm})$ $\mathrm{dCa} / \mathrm{d} \mathrm{t}$ : 許容軸方向伸縮速度 $(\mathrm{mm} / \mathrm{m}$ i $\mathrm{n})$

建築研究所の実験では、許容伸縮量より少ない伸縮で、試験体が 大きな音を発して壊れたため、実験は加力装置の油圧が低下したこ とを確認して荷重支持能力を失ったと判定した。 
一方、日本建築総合試験所の実験では、伸縮がピークに達した後、 ピークから $3 \mathrm{~mm}$ 伸縮量が下がった時点で実験を終了した。これは 試験体が座屈するまで実験を続けると、座屈による試験体変形のた め耐火加熱炉から試験体を取り出すことが困難になることを配慮し た処置である。従って、日本建築総合試験所の実験結果は荷重支持 能力を失わない時点のものである。この結果を建築研究所の崩壊温 度と直接比較することは、共通の判定基準による結果でないため適 当でない。これを補正するため建築研究所の結果から作成した、伸 縮のピークから伸縮量が $3 \mathrm{~mm}$ 下がった時点の平均鋼材温度と崩壊 温度との関係を図ー 5 に示す。データは 7 ケと多くはないが、他に

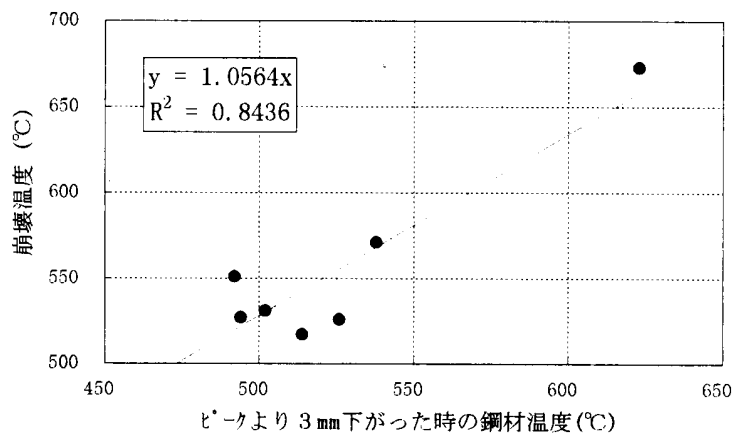

図一 5 データ補正関倸一建筑研究所の結果より

良い補正方法もないことから、この図により日本建築総合試䀦所の 結果を崩填温度に補正した注1)。

図一 6、7に建築研究所と日本建築総合試験所の試験結果を平均 鋼材温度と伸縮の関保として示す。これらの図より、柱が崩壊する

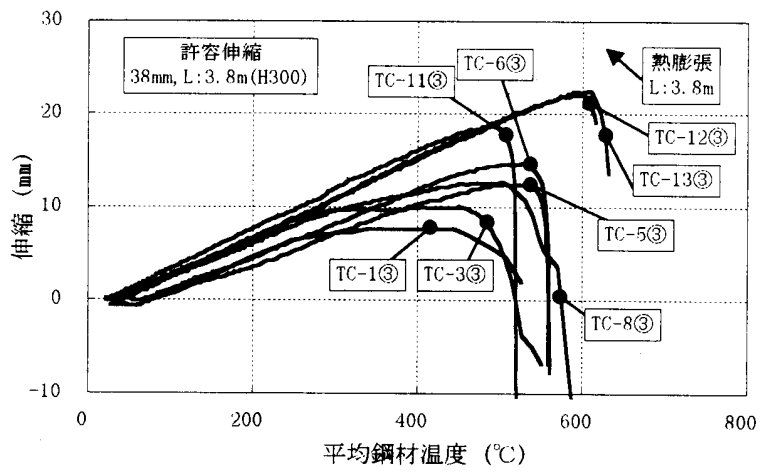

図-6 平均鋼材温度と伸縮-建策研究所

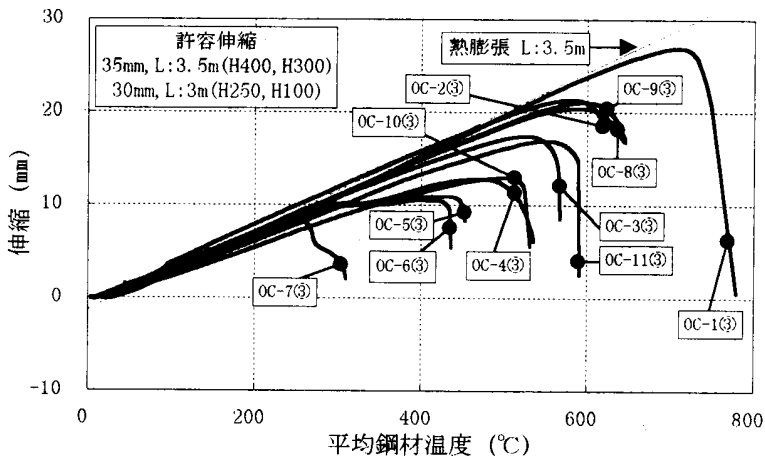

図-7 平均鋼材温度と伸縮-日本建等総合試联所

最終段階では鋼材温度の上年に伴ない急激に伸縮が低下し、建築研 究所の結果より柱の元の長さから約 $10 \mathrm{~mm}$ 短かくなるまでに荷重 支持能力を失っていることが理解できる。これは式（1）による許
容伸縮量（38 $\mathrm{mm}$ ) に比較して小さい。さらに詳細に伸縮曲線を 観察寸ると荷重の大きい試験体では約 $300^{\circ} \mathrm{C}$ の鋼材温度から伸縮 がやや減少に転ずる傾向が見られる。また、荷重支持能力を失う銅 材温度は約 $300 \sim 800^{\circ} \mathrm{C}$ 範囲にあることも分かる。

一方、表一 1 の同一寸法部材についての荷重の大小から、荷重が 大きければ荷重支持能力を失う鋼材温度は低下寸る傾向にあること も理解できる（例えばOC $-1 \sim 7 ） 。$

図一6、7 には鋼の熱膨張 $\left(12.18 \times 10^{-6}{ }^{\circ} \mathrm{C}^{-1}\right)$. による伸び の線を示してあるが、この直線は伸縮量が诚少し始める前の伸縮傾 向と一致している。すなわち、柱の伸縮は、柱が十分余裕を持って 荷重を支持している範囲では熱膨張による伸びが主要成分で、これ に温度上昇にともなう䤡柱の性能低下による縮みが重なったものと 考えられる。

なお、実験後の試験体観察によれば、大きく変形した柱は中央部 のフランジに局部座屈が発生し、弱軸回りの変形 (ウエブ面外方向) により「く」の字に大きく変形していた。

偏芯圧縮の結果と文献 [2] の再現実験の結果については次節で 述べる。

\section{4 崩壊温度と崩壊荷重比}

ここでは柱の崩壊温度と崩壊荷重比について考察する。崩壊荷重 比による考察は、鋼材温度上昇による高温坐屈耐力の低下を、常温 の座屈耐力からの低下として検討するためである。

実験で得た鉄骨柱の崩壊荷重比と崩壊温度の関係を図一 8 に示す。

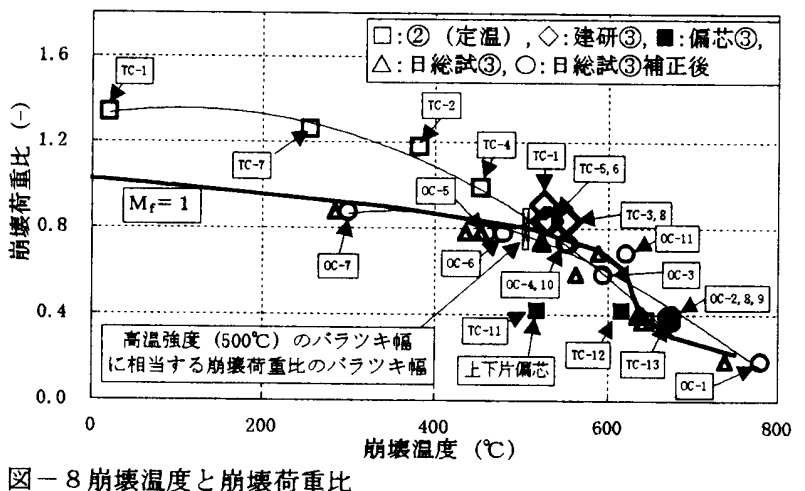

この図には建築研究所の実験(2)，(3)の結果と日本建築総合試験所の 実験(3)の結果及びそれを補正したものが、それぞれの崩壊温度の近 似曲線（細線）とともに描かれている。両曲線とも崩壊温度の上昇 に伴い崩壊荷重比は低下している。そして日本建築総合試験所の結 果として約 $780^{\circ} \mathrm{C}$ (補正後) で崩壊荷重比約 0.2 になっている。 2 つの細線は約 $300 \sim 500^{\circ} \mathrm{C}$ 範囲で差があり、崩壊温度 40 $0^{\circ} \mathrm{C}$ では建築研究所の崩壊荷重比は約 1.1 1 で日本建築総合試験所 のそれは約０９である。この差は主に鋼強度のバラッキに起因す るものと考えられるが、他の原因、例えば球座の回転拘束、初期た わみ等の影勧も含まれよう。

一方、実験した鉄骨柱の常温での長期許容圧縮荷重は崩壊荷重比 で約 O. 6 だから（正確にはH 400 ○゙．63、H 30 Oで0. $61 、 H 250$ で0.59である)、対応寸る崩壊温度は約 $590^{\circ} \mathrm{C}$ である（偏芯は除く）。

中心圧縮試験で崩壊荷重比が同じ（約 O.4）でH形銅の断面寸 
法を変えた ( H $400 、 H 300 、 H 250) 、 3$ 試験体 $(\mathrm{OC}-$ 8(3)，2(3)，9(3)の結果は、それぞれ640、635、640 00 であることから、崩壊荷重比が同じであれば、この程度に断面寸法 が変わっても、鋼材温度はほぼ同じであることが理解できる。なお、 これら断面寸法を変えた柱の細長比は $34 、 46 、 55$ であり、実 際の建物では柱の細長比が 4 ○以下の場合が多い15) とされる状況 に対応している。

偏芯圧縮試験では崩壊荷重比約 0.4 で上下片偏芯させた試験体 （T C-1 1 (3)）の崩壊温度は他の 2 偏芯試験体より低い5 $17^{\circ} \mathrm{C}$ で、上片偏芯（TC-12 (3)）では6 $16^{\circ} \mathrm{C}$ 、上下逆偏芯（TC-

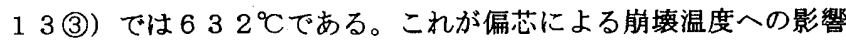
である。上下片偏芯の崩壊温度が他の 2 偏芯試験体より低いのは、 偏芯圧縮により柱上下端に導入されたモーメントによる柱高さ中央 の曲げ変形が、この試験体で最も大きくなるためであると考えられ る。

文献 [2]の実験結果と比較する目的で実施した 2 試験体の伸縮 のピークから $3 \mathrm{~mm}$ 下がった時点の平均鋼材温度はOC-10 (3) (H 200$)$ で $525^{\circ} \mathrm{C} 、 \mathrm{OC}-11$ (3) $\left(\begin{array}{llll}\mathrm{H} 10 & 0\end{array}\right)$ で $589^{\circ} \mathrm{C}$ で ある。これに対応寸る文献 2 )の結果注2) は、それぞれ $241^{\circ} \mathrm{C}$ と $504{ }^{\circ} \mathrm{C}$ である。その差は前者が文献の結果より $284^{\circ} \mathrm{C}$ 低く、後 者が文献の結果より $85^{\circ} \mathrm{C}$ 低い。特に、前者 $(\mathrm{OC}-1 \mathrm{O}$ (3) で差 が大きいが原因は明らかではない。しかし、差を生じた原因の一部 には、注 2 で述べた崩填の判定基準の差が影響していると考えられ る。ちなみに、細長比の大きい場合の崩壊温度への影響については、 実験結果が1つ（細長比 121 のOC-11 (3)）で、比較するのに 必要な実験条件による結果もなかったため明らかに出来なかった。

\section{4. 崩塄温度と伸縮の予测式および龬材強度}

ここでは崩壊温度と伸縮の予測式の提案と鋼材降伏強度の崩壊荷 重比への影響について述べる。崩壊温度の予測式は主要パラメータ 一を崩壊荷重比とし、これに偏芯と断面内温度の不均一による効果 を考慮したものである。詳しくは 4.1節で述べる。伸縮の予測式 は、熱膨張による伸びと温度上昇にともなう鋼柱の性能低下による 縮みの和で構成されると考え、鋼の性能低下による縮みは崩壊温度 で飽和する（縮みが無限大になる）とするものである。詳しくは 4 . 2 節で述べる。

上記の予測式は、熱膨張を除いた鉄骨柱の「伸縮一平均鋼材温度」 関係が鉄骨梁の「たわみ一平均鋼材温度」関係に極めて類似してい たことから、梁と同様な考え方によりモデル化したものである ${ }^{15) 。 ~}$ 予測式に組み込まれた各定数は実験データに最小 2 乗法を適用し て決定した。

\section{1 崩壊温度の予測式}

図-8で、実験結果の差は低い鋼材温度で大きいが、柱の常温座

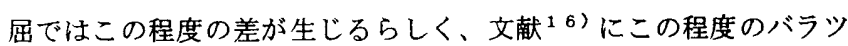
キを示す座屈データが示されている。ここでは建築研究所と日本建 築総合試験所の違い（図中の 2 細線）をモデル化するために新しい バラメーター $M_{f}$ を導入する。 $M_{f}$ は常温での崩埢荷重比を $\mathrm{M}_{\mathrm{f}}$ で除 した時 1 になるように選ぶ（これは常温の崩壊荷重比と同じ値）。 従って、建築研究所のデータに対する $\mathrm{M}_{\mathrm{f}}$ は $34{ }^{\circ} \mathrm{C}$ 結果から 1 .
33 とする。一方、日本建築総合試験所では常温の結果がないため、 常温から高温までの結果が揃っている建築研究所の結果と崩壊荷重 の形が相似であると仮定し、崩壊温度 $301{ }^{\circ} \mathrm{C}$ (補正後の值) のデ 一タから常温のM $\mathrm{f}$ を0.94 とした。

予測式は崩壊温度を修正崩壊荷重比（崩壊荷重比／ $\mathrm{M}_{\mathrm{f}}$ ）の 3 次 式で近似し、偏芯量と鉄骨断面内温度の不均一による影響は崩壊温 度に線形で影響するとした式（3）蛙案する。なお、偏芯量は試

$$
\begin{aligned}
& c \mathrm{~T}_{\mathrm{f}}=\mathrm{C}_{0} \times \mathrm{N}_{\mathrm{rn}}^{3}+\mathrm{C}_{1} \times \mathrm{N}_{\mathrm{rn}}^{2}+\mathrm{C}_{2} \times \mathrm{N}_{\mathrm{rn}}+\mathrm{C}_{3} \times \mathrm{e}+\mathrm{C}_{4} \times \mathrm{T}_{\mathrm{d}}+\mathrm{C}_{5} \\
& \text { ここに } \mathrm{C}_{\mathrm{c}} \mathrm{T}_{\mathrm{f}}: \text { 崩壊温度 }(\mathrm{C}) \\
& \mathrm{C}_{0} \sim \mathrm{C}_{5}: \text { 定数 (無次元でない) } \\
& \left(C_{0}=-4407.2, C_{1}=6719.2, C_{2}=-3455.2, C_{3}=-799.27, C_{4}=-18.48, C_{5}=1228.1\right) \\
& \mathrm{N}_{\mathrm{rn}} \text { ：修正崩壊荷重比（軸荷重/常温座屈荷重/ } \mathrm{M}_{\mathrm{f}} \text { ) } \\
& \mathrm{M}_{\mathrm{f}}: \text { 強度パラメータ } \\
& \text { e : 無次元偏芯量（柱高さ中央偏芯/H型鋼のせい) } \\
& \mathrm{T}_{\mathrm{d}} \text { : 両フランジ最大温度差/ } \mathrm{H} \text { 型鋼のさい }(\mathrm{C} / \mathrm{mm})
\end{aligned}
$$

験体の高さ方向中央の曲げモーメントを代表する值（図ー 1 の記号 e ）を選び、鉄骨断面内温度の不均一による変形の効果はH形鋼の 両フランジ間の最大温度差で代表させ、それぞれを $\mathrm{H}$ 形鋼のせいで 除した。

実験崩壊温度と予測崩壊温度の関係を図ー9に示す。これより予

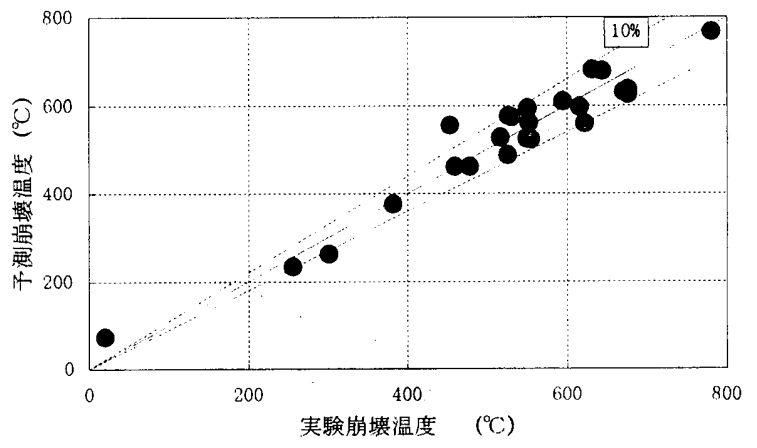

図 -9 崩壊温度の予測值結果と誤差

測值は実験値のほぼ士10\%の笧囲にある。なお、式（3）による 崩壊温度は、本来、力学的解法に基づき、軸力、初期変形、偏芯量、 断面温度の不均一による効果を考慮した次元に矛盾のない定式化が なされるはずであるが、ここでは崩㯰温度に対して感度を有するパ ラメーターを抽出し、簡単な実験式としてモデル化したため、定数 は次元を持つ形となった。また、式の各定数は実験結果を基に統計 的に得られたものであり、異なる実験結果にたいしてはその值も変 化する。したがって、今回の実験条件と異なる場合に式を用いるに は十分な注意が必要である。これらのことは式（4）、（4'）に ついても言える。

\section{2 崩壊過程の伸綰予測式}

鉄骨柱は鋼材温度上昇にともなって伸縮が増加し、上記の崩買温 度で荷重支持能力を失う。ここでは、この過程を熱膨張による伸び と鋼柱の材料性能低下による縮みの影響を表わ寸飽和曲線の和で近 似する。飽和曲線は飽和への速さを表す係数で特徵づけられるが、 この係数を崩壊温度に比例し、塑性軸力比に反比例するとする式 （4）、（4'）を実験式として提案する。予測結果と実験結果の 


$$
\begin{aligned}
& \delta=L \times\left(S_{t}+E_{x} \times{ }_{C} T\right) \\
& { }_{\mathrm{C}} \mathrm{T}={ }_{\mathrm{C}} \mathrm{T}_{\mathrm{f}} \times\left\{1-\exp \left(\mathrm{K}_{1} \times \frac{\mathrm{c}_{\mathrm{f}}}{\sigma_{\mathrm{r}}} \times \mathrm{S}_{\mathrm{t}}\right)\right\} \\
& \text { ここに } \delta \text { : 伸縮量 }(\mathrm{mm}) \quad \mathrm{L} \text { : 柱高さ }(\mathrm{mm}) \\
& \mathrm{S}_{\mathrm{t}} \text { : 柱ひずみ (一) } \quad \mathrm{E}_{\mathrm{x}} \text { : 線熱膨張率 }\left(12.18 \times 10^{-6} \mathrm{C}^{-1}\right) \\
& \mathrm{c}^{\mathrm{T}} \text { : 鋼材温度 ( } \mathrm{C} \text { ) } \mathrm{K}_{1} \text { : 定数 (無次元でない) } \\
& \sigma_{r}: \text { 塑性軸力比 }(-) \quad\left(K_{1}=1.2187\right)
\end{aligned}
$$

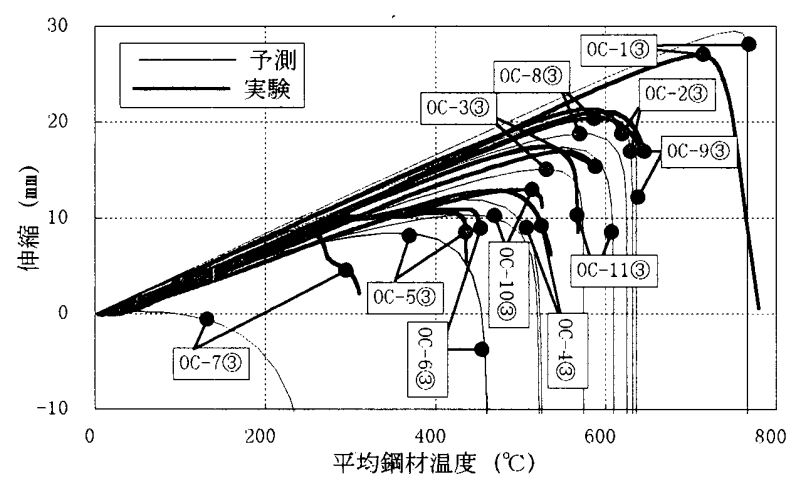

図一 10 伸縮の実験と予測の比較一日本建䇣緿合圾験所

比較を図ー10に示す。これより予測結果は崩壊温度が高ければ(4 O $0{ }^{\circ} \mathrm{C}$ 以上) 赛験結果に良く対応していることが理解できる。な拉、 この図には鋼材寸法、荷重等を変えた日本建築総合試験所の結果を 示してあるが、建築研究所の比較結果も誤差は少し大きいが同様な 傾向にある。

\section{3 龬材降伏強度（常温及び $500^{\circ} \mathrm{C}$ ) と $\mathrm{M}_{\mathrm{f}}$ について}

一般に鋼材はバラツキを有するため、製造段階では許容応力度の 基準值より高い強度を目標に製造管理される。強度が高くなれば柱 の座屈耐力も大きくなる。このため常温での座屈耐力は鋼材の降伏 強度で無次元化して整理されることが多い。本実験においても常温 試験体の崩壊荷重比が 1.334 だから降伏強度は $2.4 \mathrm{tonf} / \mathrm{cm}^{2}$

\begin{tabular}{|c|c|c|c|c|c|c|c|c|c|c|}
\hline \multirow{2}{*}{\multicolumn{3}{|c|}{$\begin{array}{c}\text { 試呀体記号 } \\
\text { (鉿程重, 製造会社の記号) }\end{array}$}} & \multirow{2}{*}{$\begin{array}{c}T C-1 \sim 10 \\
\text { (SN400B, } \\
\text { SN 社) }\end{array}$} & \multirow{2}{*}{$\begin{array}{l}\mathrm{TC}-11 \sim 13 \\
(\mathrm{SS} 400, \\
\mathrm{SN} \text { 社) }\end{array}$} & $\begin{array}{l}\alpha_{-} \\
1,4\end{array}$ & $\begin{array}{c}\propto c-2,3 \\
5,6,7\end{array}$ & $\propto-8$ & $\propto^{-9}$ & $\propto C-10$ & $\propto-11$ \\
\hline & & & & & \multicolumn{6}{|c|}{ (SN400B, NK 社) } \\
\hline \multicolumn{3}{|c|}{ ミルシート値 } & 3.48 & 2.90 & 3.23 & 3.17 & 3.13 & 3.11 & 3. 55 & 3.45 \\
\hline \multirow{3}{*}{$\begin{array}{l}\text { 試 } \\
\text { 策 } \\
\text { 贲 } \\
\text { 多 } \\
\text { ル }\end{array}$} & 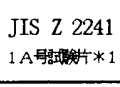 & \multirow{2}{*}{ 室温 } & なし & なし & $\begin{array}{l}2.82 \\
2.85 \\
2.95 \\
\end{array}$ & $\begin{array}{l}2.93 \\
3.03 \\
3.04 \\
\end{array}$ & $\begin{array}{l}3.06 \\
3.00 \\
2.95 \\
\end{array}$ & $\begin{array}{l}3.03 \\
2.94 \\
2.95 \\
\end{array}$ & $\begin{array}{l}2.97 \\
3.18 \\
3.19 \\
\end{array}$ & $\begin{array}{l}3.24 * 2 \\
3.41 * 2 \\
3.27 * 2 \\
\end{array}$ \\
\hline & \multirow{2}{*}{ 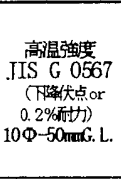 } & & $\begin{array}{l}2.87 * 3 \\
2.70 * 3 \\
3.03 * 3 \\
\end{array}$ & $\begin{array}{l}2.72 \\
2.61\end{array}$ & $\begin{array}{l}2.85 \\
2.67\end{array}$ & 2.81 & 2.95 & 2.89 & 3.11 & $3.23 * 4$ \\
\hline & & $\begin{array}{l}500 \\
{ }^{\circ} \mathrm{C}\end{array}$ & $\begin{array}{l}1.48 * 3 \\
1.38 * 3 \\
1.50 * 3\end{array}$ & $\begin{array}{l}1.55 \\
1.50\end{array}$ & $\begin{array}{l}1.59 \\
1.58\end{array}$ & 1.44 & 1.51 & 1.27 & 1. 42 & $1.55 * 4$ \\
\hline
\end{tabular}
より高かったと予想される。事実、ミルシートの降伏强度は 3.4 8 tonf $/ \mathrm{cm}^{2}$ である。

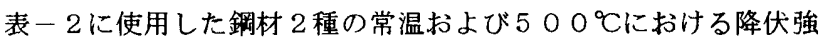
度を示す。常温での降伏強度は 3 種類あり、ミルシート值、試験体

表一2 圾験体の降状強度（高温 $500^{\circ} \mathrm{C}$ を含む）

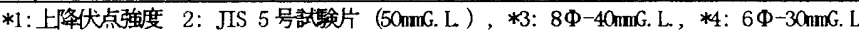

鋼材から試料を採取した引張試験結果の值（ＪＩＳＺ２２２４1_1 A号試験片) および高温引張強度用の試験片による值（ＪＩＳＧ０ 567 ) である。これらの測定值に文献 ${ }^{17)}$ によるS S 41 の降伏 強度分布を加えて図一１１に示寸。これより降伏強度がミルシート、

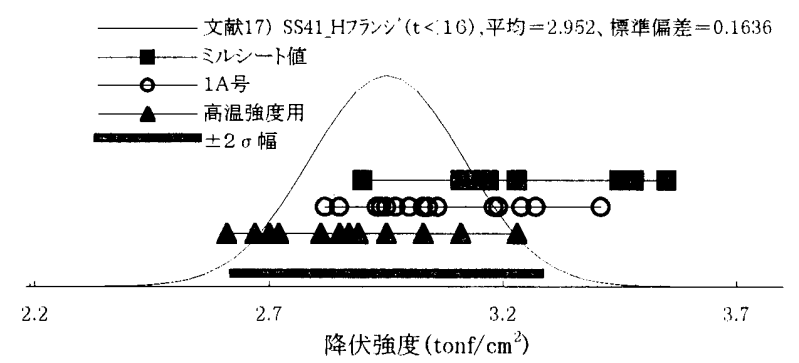

図 -11 鋼材の常温引張降伏強度

$1 \mathrm{~A}$ 号試験片、高温引張強度試験片の順に低下し、ミルシート值と $1 \mathrm{~A}$ 号試験片の一部に、分布標準偏差の 2 倍の範囲を超える値が見 られる。

一方、図一8において、常温での降伏強度が高いことにより崩壊 荷重比が大きくなったと考えられる建筑研究所の結果（室温〜約 5 $\left.00{ }^{\circ} \mathrm{C}\right)$ に比較して、同程度の降伏強度を有寸る試験体 $O C-5$, 6,7 の崩壊荷重比が約 $300 \sim 450^{\circ} \mathrm{C}$ 範囲で小さい。このこ とは常温降伏強度が同程度であることからは理解できない。さらに、 高温におりる鋼の忘力一歪み曲線には降伏棚が見られなくなるため、 座屈耐力性状は常温の忘力一歪み曲線に基づく耐力性状と異なるこ とも考えられる。

これらのことから、ここで使用した鋼種の高温領域を含む座屈耐 力の全体を明らかにするには、降伏強度の逗いを含む結果を知るこ とが必要であると考えたため、降伏強度による無次元化の処理を行 わなかった。

高温降伏強度（下降伏強度あるいは０．2\%オフセット）のバラ ツキについては、鋼材温度 $500{ }^{\circ} \mathrm{C} て ゙$ 検討する。なぜなら、この温 度で高温引張試験を実施していること、およびこの温度は長期許容 圧縮荷重が作用した柱の崩㯰温度約 $590^{\circ} \mathrm{C}$ (3.4節) に比べや や低いが、この温度より少し高い温度域に実験結果が多いので、比 較するのに都合が良いと考えたためである。

高温降伏強度のサンプル数は 12 と少ないが、平均值 1.48 tonf $/ \mathrm{cm}^{2}$ で、母標準偏差（ $\sigma$ ）は０．０８７である。正規分布を仮 定寸れば平均值士 2 oが約 $95 \%$ の確立で生じる範囲である。この 強度のバラツキ幅が崩壊荷重比に直接対匛寸ると仮定した場合の範 囲 $\left(\mathrm{M}_{\mathrm{f}}=1\right.$ で崩壊温度 $500^{\circ} \mathrm{C}$ 崩壊荷重比を中心とする \pm 11 . $7 \%$ 範囲、士2 0 に相当）を図一 8 に示す。 この範囲は、直ぐ右の実験結果のバラツキ幅に ほぼ対応しているが、本来、高温降伏強度の崩 壊荷重比への影響を実験的に調べるためには、 高温強度をできるだけ大きく变化させて感度を 調べる必要がある。本研究では、それを実施し ておらず、この結果から強度のバラッキ幅（士 $2 \sigma)$ のみにより崩壊荷重比のバラツキ幅を説 明することは適切でないと考える。

次に $M_{f}$ について説明する。図一 8 の崩壊荷重 比一崩壊温度の結果は、常温及び高温の降伏強 度はもとより、柱の初期変形、鋼材断面内温度 の不均一、載荷中心位置や荷重の誤差および実験装置特性などの崩 壊荷重比に影㗽する全ての効果を含んでいる。これらの影響を明ら かにし、高温座屈耐力の予測式を作ることは重要であるが相当な困 
難が予想される。そのため、ここでは実験結果を基に崩壊荷重比一 崩壊温度のバラツキを扱うための指標として $\mathrm{M}_{\mathrm{f}}$ を導入した。

\section{5. 構造上安全な崩壊温度の提案}

上で述べたように、両端ピン支持された鉄骨柱の崩壊温度は、鉄 骨寸法、試験体高さ、荷重、両フランジ温度差、偏芯量等が与えら れれば式 (3) で決定される。表一 3 に幾つかの鉄骨部材に長期許 容圧縮荷重が作用した場合の崩壊温度を計算したものを示す。なお、

表-3 鉄骨柱 )崩壊温度 (式 3 による)

\begin{tabular}{|c|c|c|}
\hline 銅材才仕様・計算条件 & $\begin{array}{c}\text { 両フランジ最大 } \\
\text { 温度差 } \mathrm{C}\end{array}$ & 崩䧇温度 ${ }^{\circ} \mathrm{C}$ \\
\hline \multirow{4}{*}{$\begin{array}{c}H 400 \times 400 \times 13 x^{2} 1, \\
\mathrm{~Np}_{2,8}=525.6 \text { tonf, } \mathrm{Nf}_{2,4}=504.9 \text { tonf, } \\
{ }_{\mathrm{D}} \mathrm{N}_{\mathrm{a}}=322.5 \text { tonf, } \\
\mathrm{L}=380 \mathrm{~cm}, \mathrm{e}=1.6 \mathrm{~cm}, \mathrm{M}_{\mathrm{f}}=1\end{array}$} & 0 & 582 \\
\hline & 25 & $570\left(538^{*}\right)$ \\
\hline & 50 & 5.58 \\
\hline & 100 & 535 \\
\hline \multirow{4}{*}{$\begin{array}{c}\mathrm{H} 300 \times 300 \times 10 \times 15 \\
\mathrm{~Np}_{2.4}=288.8 \text { tonf, } \mathrm{Nf}_{2.4}=267.5 \text { tonf, } \\
{ }_{\mathrm{D}} \mathrm{N}_{\mathrm{a}}=165.5 \text { tonf, } \\
\mathrm{L}=380 \mathrm{~cm}, \mathrm{e}=1.2 \mathrm{~cm}, \mathrm{M}_{\mathrm{f}}=1\end{array}$} & 0 & 586 \\
\hline & 25 & $571\left(539^{*}\right)$ \\
\hline & 50 & 555 \\
\hline & 100 & 525 \\
\hline \multirow{4}{*}{$\begin{array}{c}\mathrm{H} 250 \times 250 \times 9 \times 14, \\
\mathrm{~Np}_{2.4}=221.3 \text { tonf, } \mathrm{Nf}_{2,4}=198.8 \text { tonf, } \\
{ }_{0} \mathrm{~N}_{\mathrm{a}}=119.1 \text { tonf, } \\
\mathrm{L}=380 \mathrm{~cm}, \mathrm{e}=1 \mathrm{~cm}, \mathrm{M}_{\mathrm{f}}=1\end{array}$} & 0 & 590 \\
\hline & 25 & $571\left(539^{*}\right)$ \\
\hline & 50 & 553 \\
\hline & 100 & 516 \\
\hline
\end{tabular}

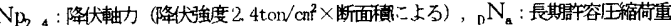

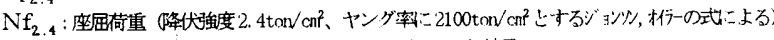

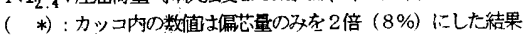

両フランジ最大温度差は0，25，50，100Cを仮定した。温 度差 $0{ }^{\circ} \mathrm{C}$ は他との比較のために、 $25^{\circ} \mathrm{C}$ は 2 時間耐火構造の B OX 型耐火被覆に認められるレベルの温度差として、50、100 H型耐火被覆あるいは耐火被覆厚さが大きくばらついた場合や加熱 が局部的に差のある場合および無被覆の鉄骨等の場合に生じるレべ ルの值として選んだ。偏芯量は鉄骨せい寸法の 4 \% (一部では $8 \%$ ) を選んだ。 $4 \%$ の偏芯量はH形鋼の寸法規格を考慮寸れば安全側の 值である。

これより崩壊温度は、鉄骨断面寸法が本研究の実験範囲程度で、 耐火構造 2 時間の被覆であれば（両フランジ最大温度差 $25^{\circ} \mathrm{C}$ ） 5 $70^{\circ}$ Cに計算される。これに予測誤差範囲士 $10 \%$ を考慮すれば、 崩壊温度は $513^{\circ} \mathrm{C}$ と提案できる。両フランジ温度差が $100^{\circ} \mathrm{C} の$ 場合は最小で $516^{\circ} \mathrm{C}$ と計算される。但し、この崩買温度はM $\mathrm{M}_{\mathrm{f}}$ が 1 の場合である。ちなみに、計算条件が同じで $\mathrm{M}_{\mathrm{f}}$ が 1 ．3の場合、 それぞれ $586^{\circ} \mathrm{C}$ と $25^{\circ} \mathrm{C}$ となる。また、偏芯量については、表 - 3 で偏芯量のみをH形鋼せいの $4 \%$ から $8 \%$ にした場合には崩壊 温度が $32{ }^{\circ} \mathrm{C}$ 低下している。

\section{6。まとぬ}

本研究により鉄骨柱の高温座屈耐力に関して、下記のことが指 摘できる。

1) 現在の耐火試験で規定されている、加熱終了時の平均許容龬 材温度の判定值 $350^{\circ} \mathrm{C}$ は、吹付ロックウール、ケイ酸カルシュ ウム板、軽量モルタルで被覆した 2 時間耐火構造においては、加 熱終了後の後追い鋼材温度上昇によっても、荷重支持能力を失っ ていない。

2）実験した鉄骨柱の高温座屈耐力（崩壊荷重比）は平均鋼材温 度（崩壊温度）の上昇とともに低下し、崩壊温度は鉄骨寸法、荷 重、偏芯量、両フランジ鋼材温度差、 $\mathrm{M}_{\mathrm{f}}$ により、式 (3) によ
り約士 $10 \%$ の精度で予測できる。しかし、鋼材の高温強度のバ ラツキと密接に関係するはずの $\mathrm{M}_{\mathrm{f}}$ を、鋼素材の高温降伏強度と の関倸において必ずしも明確にすることのできなかった点は、今 後検討すべき課題であると考える。

3）加熱された鉄骨柱の伸縮举動は、熱膨張と材料性能低下を表 わ寸飽和曲線の和として式（4）、（4'）で近似でき、崩壊温 度 $400^{\circ} \mathrm{C}$ 以上において比較的良く実験結果に一致している。

4) 本研究により、実験に用いた程度の鋼材寸法と耐火被覆で、両 フランジ温度差が $25^{\circ} \mathrm{C}$ であれば、上下球座の実験条件で長期許 容圧縮荷重を支持した柱の崩壊温度は、式（3）上り約 $570^{\circ} \mathrm{C}$ と計算される。これに予測誤差範囲土10\%を考慮すれば、崩壊 温度は $513{ }^{\circ} \mathrm{C}$ と提案できる。但し、この温度はM f が 1 の場合 である。一方、偏芯量については、偏芯量をH形䤡せいの $4 \%$ \%か ら 8 \%に增加させた場合に崩買温度が $32^{\circ} \mathrm{C}$ 低下する。

\section{7. 謝辞}

本研究は、斎藤光先生を委員長とする『建設省総合技術開発プロ ジェクト「防・耐火性能評価技術の開発／棈造分科会」』の下で行 われた実験結果を取りまとめたものである。研究の実施にあたって は、委員長ならびに関倸した多くの委員の方々に御指導・御協力を いただきましたことを心から感謝いたします。また、実験実施に当 たっては関係団体ならびにその関係者の協力を頂きました。大変あ りがとう御座いました。

\section{参考文献}

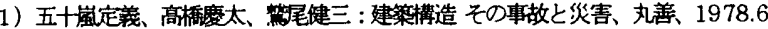

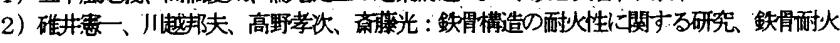
構造研究会、 19643

3）高野孝次：鉄骨構造の耐火性能に関する研究 学位論文、1983.10

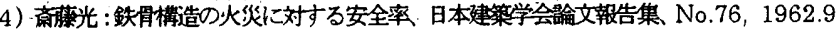

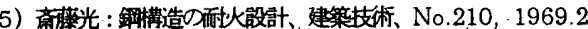

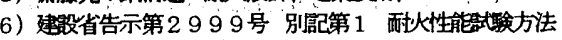

7） J I S A 1304 建築棬造部分八耐火試倹力法、1975

8) I SO $834-1,2 、 6$ 、Fire Resistance Tests - Elements of building construction.. Draft，1995 (なお、最新版は1999.9に確定している)

9) BS 476 : par t 20 , Fire tests on building materials and structures

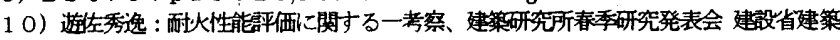
研究所、平成 8.5

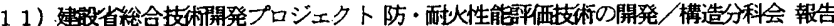

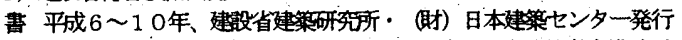

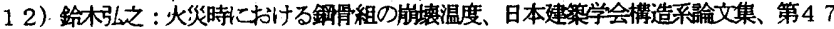
7 号 pp.147-156 1995.11

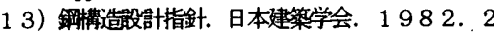

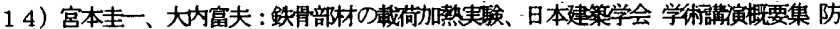
火 pp.1397-13981994.4 (東海)

15）茂木武，他 3名 : 㬰大鉄骨梁の高温曲け耐力に関する実験的研究 日本建築学会論 文集（權造系）投稿中

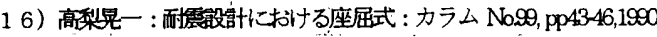

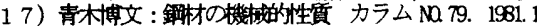

注1このような補正方法はIS O O耐火試験方法に規定されていないが、 荷重支持能力を失う時点での崩㙹温度を比較するため、建築研究所の結果 を用いて補正した。補正は2つの判定值の相関関係を根拠とするものであ るが、少ないデータを基にしており精度的には検即の余地のあるものと考 えられる。

注 2 文献 [2] では、「柱の伸縮が漸減し、ついにとまった後、急激に縮み はじめて崩買した」とする観察に基づき、伸縮が急変した時点で座屈した と判定（文献のグラフによれぼ伸縮のピークより少し手前）しており、こ こでの値は文献の值を採用した。しかし、この判定方法は、本研究におい て用いた I S O規格や日本建築総合試験所での判定基準とは異なっており、 本研究の崩垻温度より低い銅材温度結果を示すと予想される。 